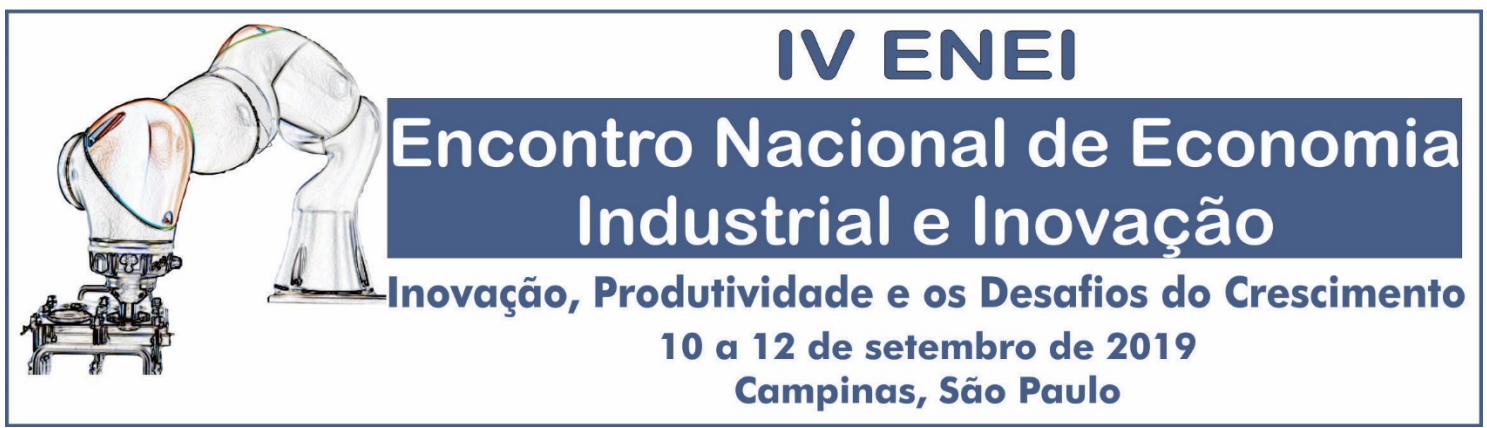

The relationship between public support and degree of novelty of innovation in Brazil

\author{
Suelene Mascarini \\ Post-doctoral Researcher at Innovation Systems, Strategy and Policy (InSySPo) \\ program of University of Campinas (Brazil) \\ Renato Garcia \\ Professor at Institute of Economics at University of Campinas, Brazil \\ Nicholas Vonortas \\ São Paulo Excellence Chair, University of Campinas, Brazil
}

\begin{abstract}
This paper investigates the association between public support and degree of novelty of innovation in Brazil. We examine empirically two kinds of public funding, for $R \& D$ and for general activities (including R\&D). The data source is edition of Brazilian Innovation Survey (PINTEC 2008 and 2011). The study provides evidence that both public support are related to the degree of novelty of innovation. We conclude that the public support for R\&D is related with higher degrees of innovation than public support for general activities. Therefore, the policies should be formulated thinking on the degree of novelty of the innovation to be achieved.
\end{abstract}

Keywords: Degree of novelty of innovation; public support; $R \& D$ and non-R\&D JEL Code: O31; O38; O32

Resumo: O trabalho investiga a relação entre o financiamento publico e o grau de novidade da inovação no Brasil. Nós examinamos empiricamente dois tipos de suporte público, os que são para atividades de $\mathrm{P} \& \mathrm{D}$ e os que incluem atividades não relacionadas à $\mathrm{P} \& \mathrm{D}$. Os dados são provenientes de duas edições da PINTEC, PINTEC 2008 e 2011. Nosso estudo fornece evidencias empíricas de que o grau de novidade de inovação está associado ao suporte publico tanto relacionado somente a P\&D como ao que não voltado à $\mathrm{P} \& \mathrm{D}$. Além disso, concluímos que o suporte público para $\mathrm{P} \& \mathrm{D}$ estão relacionado aos mais altos graus de novidade de inovação, como para o mundo, enquanto que o suporte que inclui não $\mathrm{P} \& \mathrm{D}$ está associado aos mais baixos graus de novidade, como para a firma.

Palavras-chave: Grau de novidade da inovação; suporte público para $P \& D$ e não $P \& D$

Código JEL: O31; O38; O32

Area Temática: Políticas de Ciência, Tecnologia e Inovação 


\title{
The relationship between public support and degree of novelty of innovation in Brazil
}

\begin{abstract}
This paper investigates the association between public support and degree of novelty of innovation in Brazil. We examine empirically two kinds of public funding, for $R \& D$ and for general activities (including $R \& D$ ). The data source is edition of Brazilian Innovation Survey (PINTEC 2008 and 2011). The study provides evidence that both public support are related to the degree of novelty of innovation. We conclude that the public support for $R \& D$ is related with higher degrees of innovation than public support for general activities. Therefore, the policies should be formulated thinking on the degree of novelty of the innovation to be achieved.
\end{abstract}

Keywords: Degree of Novelty of Innovation; public support; $R \& D$

JEL Code: O31; O38; O32

\section{Introduction}

Public support for innovation is a practice adopted by several countries. Many firms, especially the new, have a lack of private capital to innovate, since the process of innovation is surrounded by uncertainties and imperfections. In this way, it is often necessary for the public sphere to stimulate innovations through subsidies, which can be targeted at a specific sector, a group of companies, or even directly at firms. In this sense, the use of public support can be part of the firm's strategy as a way of dividing the risks of innovation, foster research and scientific and technological infrastructure.

In Brazil, studies that evaluate the distribution and effect of public financing for innovation have been produced (Júnior and Prince 2015; Colombo and Cruz 2018; Rapini 2013). However, studies that evaluate and differentiate the impact of public support on the degree of novelty of innovation in Brazil are still rare. It is this gap that this paper intends to fil, when assessing whether public support for R\&D and for general activities (R\&D and non-R\&D) can generate different degrees of novelty of the innovation.

We use on a broad firm level survey collected by Brazilian Innovation Research in 2008 and 2011 (PINTEC 2008 and 2011). We distinguished the degree of novelty of innovation by the firms that did not innovate, firms that introduced innovation to firm, firms that introduced innovation to the industry (or domestic market), and firms that introduced innovation to the world between 2009 and 2011. So, we do not look only if there is innovation or not, but also the degree of novelty of innovation in terms of market.

Public support is differentiated into two measures. First, public support for R\&D involve in firms that received incentives for acquisition of internal and external $R \& D$ activities in 2008. Second, public support for general activities consist in firms that got supports for acquisition of other external knowledge, software, machinery and equipment, personal training, introduction of technological innovations in the market, other preparations for production and distribution and internal and external R\&D activities in 2008 (R\&D and non-R\&D).

This paper is organized into four sections, excluding this introduction. The first section presents the main conceptual debates regarding the degree of novelty of innovation and 
public support. Section two presents our data and the methodology used to conduct the empirical research. Section three presents the main results of the analyses as well as a discussion of those results. Finally, final section contains the conclusion of the study.

\section{Background}

In the literature there is different approaches to differ degree of novelty of the innovations. Probably, in terms of market achieved the definition most used in the literature was defined by OECD that distinguee three degree of novelty of innovation: new-to-the-firm; new-to-the-industry (or domestic market) and new-to-the-world. This distinction is related to the fact that other firms already have introduced or not an innovation. Thus, it is considered an innovation to the firm any change that has already been introduced by other firms, but is new-to-the-firm that introduces it. An innovation is new-to-the-industry in case it is already present in other(s) market(s) but not to the market that the firm introduce it. Finally, the innovation is new-to-the-world when the firms introduce innovation that is new in all national and international market and industries. Thus, there is an orderly sequence in the classification of degree of novelty of the innovation. The lower degree is given by new-to-the firm and higher degree is the new-to-the world (Manual 2005, 69-70).

There is a growing body of empirical evidence on the factors that explain degree of novelty of innovation. There is no agreement on a single explanation, and various alternative conceptual frameworks are used which stress the importance of different explanatory factors can be lead to an improvement of firms innovation performance. However, these factors appear to focus on how firms work to compensate for internal and external resources deficits, and whether they define strategies to enhance their innovation capabilities. These deficits are common, especially the new and small firms, since the process of innovation can be quite costly because is surrounded by uncertainties and imperfections. In this way, it is often necessary for the public sphere to stimulate innovations through subsidies, which can be targeted at a specific sector, a group of companies, or even directly at a firm (Cohen and Levinthal 1990; McDermott and O'Connor 2002; Amara et al. 2008; Feldman and Kelley 2003).

According to Freeman and Soete (2008), the State with its power to generate market and encourage through public policies can often assume the role of agent inducing innovation and technological development through mechanisms that support innovation. In this way, public funding can enable the strengthening of research and scientific and technological infrastructure. Therefore, it can be part of the firm's strategy as a way of dividing the risks and uncertainties involved in the innovation process, making it an important tool for firms to innovate to a higher or lower degree. The defence of basic research funding as well as education are clearly present in the works of Nelson (1959) and Arrow (1962), arguing that private expenditure would tend to be lower than economically and socially desirable levels if left to the market (Cohen and Levinthal 1990; Feldman and Kelley 2003).

In the last decades the empirical literature has sought to measure the impact of public policy on innovation. According to Georghiou (1994, 2002) in this context the researches can be divided into three main streams. The first stream of research focuses on public policy effect on innovation input, traditionally interpreted as R\&D expenditure increase (Colombo and Cruz 2018; Jr, Sergio, and Porto 2012; Luke 
Georghiou 2002; L Georghiou 1994; Cin, Kim, and Vonortas 2017). The second stream of research focuses on the impact of public policies on the behaviour of firms that are related to the strategic change of firms (Colombo and Cruz 2018; Neicu, Teirlinck, and Kelchtermans 2016). Finally, the third stream of research focuses on the impact of policy on innovative results, typically if there is or not innovation, or patent (Colombo and Cruz 2018; L Georghiou 1994). This study is embedded third stream of research, since it explores the association between two kind public support, for R\&D and general innovation activities, and degree of novelty of the innovation in Brazil.

\section{The Brazilian innovation policy}

Since early 2000s, Brazil has experienced shifts in the goal to promote and consolidate the relationship between different institutions (political, scientific and industrial sector), aiming to reinforce the National System of Innovation (NSI). These shifts involved technological programs focused on specific needs and allocation of financial resources in development of industrial sectors and the dissemination and implementation of direct public support to innovative firms.

The creation of a Sectorial Fund between 1999 and 2002 represent one of these advances. The aim of the Sectorial Fund is scientific and technological development of specific sectors, training and qualification of human resources and the development of projects of collaborations between companies and universities, higher education institutions or research centres, aiming to increase production and productivity (“FINEP” n.d.)

In addition, two laws represent the effort to integrate the National System of Science, Technology and Innovation (STI) with Industrial policies: the Law 10,973/04 - Lei da Inovação (Brasil 2004) and the Law 11,196/05 - Lei do Bem (Brasil 2005). The Law $10,973 / 04$ was created with the main purpose of stimulating partnerships between academic institutions and the Brazilian productive sector and Law 11,196/05, following framework and experience of other countries, established special tax incentives for firms that invest in R\&D.

Both laws constitute an inflection in the trajectory of the Brazilian management system of intellectual property and of technology transfer. The laws provided legal protection and defined incentives for the commercialization of the results of scientific and technological research (Arbix and Consoni 2011; Colombo and Cruz 2018). In addition, it also allowed direct government subsidies for innovation in firms. Public funds could be transferred as non-reimbursable funds to firms, sharing the costs and risks of innovative activities. According to Arbix and Consoni (2011), these laws represent an important change of the national innovation policy, because its created tools to support companies in several dimensions: increasing mechanisms for fiscal incentives to R\&D; subsidy programs for technological development projects; mechanisms of subsidies to researchers in companies; and financing programs for venture capital innovation (Arbix and Consoni 2011) .

Quantitative studies to analyse the impact of tax incentives for innovation in Brazil are being done. In general, these studies concluded that polices had a positive effects on firm's R\&D, technical personnel and export levels (Jr, Sergio, and Porto 2012; Colombo and Cruz 2018; Júnior and Prince 2015). However, there is no study that evaluates the 
relationship of these policies with the degree of novelty of innovation in Brazil. Thus, this work advances in this direction, analysing the relationship of public support for $\mathrm{R} \& \mathrm{D}$ and for general activities and the different degrees of innovation.

\section{Empirical Model}

\subsection{Database}

In this section, we provide brief details of the datasets used, followed by a discussion of the dependent variable, the variables of interest and controls. For this research, we gathered firm-level data from the Innovation Research in Brazil (PINTEC ${ }^{1}$ ). This dataset is maintained by the Brazilian Institute of Geography and Statistics (IBGE) and it is a cross survey that covers information about activities of innovation in Brazil, such as expenditure, public support, and impact. Additionally, we collected regional-level data from the Annual Report on Social Information (RAIS) of the Ministry of Labour and merge it with PINTEC data This dataset contains the register of of formal employment, which allows us to construct regional controls.

Firm's innovative performance is observed in 2009-2011 (from PINTEC 2011), firm's for inputs (as R\&D), characteristics (as Size), public support and regional factors is 2008 (from PINTEC 2008 and RAIS 2008), following the recommendation of the European Commission (2015) to access innovation output up to ' $t+3$ '.

Note that if firm did not innovate there is not information about innovation input (as R\&D), thus, firms that did not innovate in 2006-2008 are not identified. Therefore, we database is composed only by firms that innovate in 2006-2008 and are in both PINTEC surveys (2008 and 2011). Thus, we have database composed by 7,181 firm's that innovate in 2006-2008. This is important, because that the literature suggest that firms receiving public support may have been selected by the policy-maker because they are likely to innovate, which cause sample selection bias (Cin, Kim, and Vonortas 2017). Therefore, as in our analysis all firms innovated in the past, the probability to receiving public support should be similar between them, reducing the problem of selection bias. In the figure 1 we have the representation of the construction of the database.

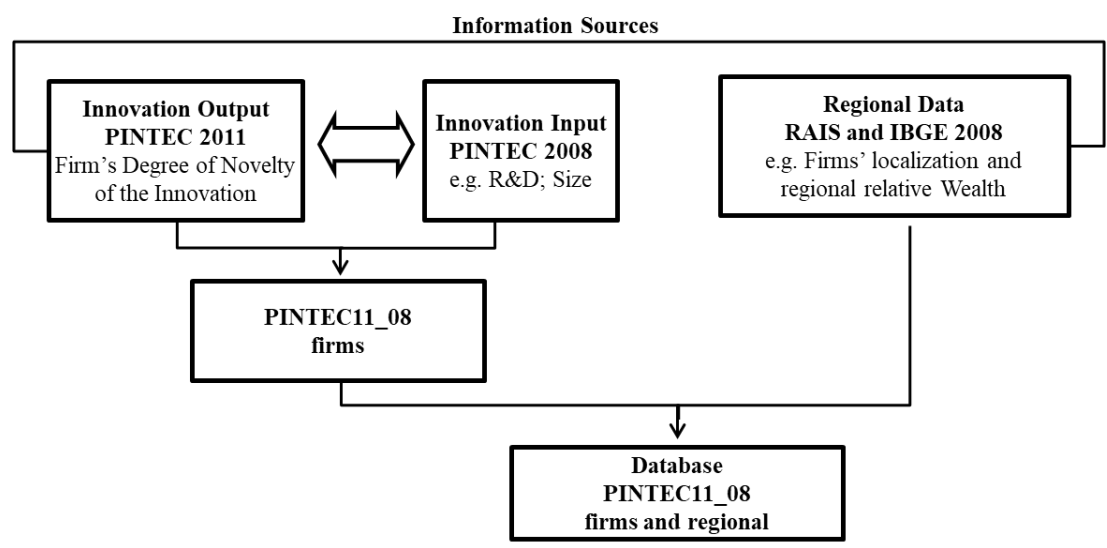

Figure 1: Database structure

\footnotetext{
1 The IBGE conducted and published a total of six editions of Innovation Research, which were PINTEC 2000 that covers the triennium 1998-2000, PINTEC 2003 (triennium 2001-2003), PINTEC 2005 (triennium 2003-2005), PINTEC 2008 (triennium 2006-2008), PINTEC 2011 (triennium 2009-2011) and PINTEC 2014 (triennium 2012-2014).
} 


\subsection{Degree of novelty of the innovation}

This aim of this paper is to examine the relationship between public support, for R\&D and general activities (R\&D and non-R\&D), and the degree of novelty of innovation in Brazil. Therefore, the dependent variable is the degree of novelty of innovation, which is a categorical ordinal variable. This information comes from PINTEC 2011, which asks to the firm to indicate if it introduced, between 2009 and 2011, any innovation. If the answer is yes, the firm was asked to indicate the degree of novelty of that innovation in terms of the market. The options were new-to-the-firm, new goods or services already available from its competitors in the domestic market (or industry); new-to-the-industry or domestic-market, new goods or services, but already available in other markets; and new-to-the-world, if the firm introduced new goods or services to the global market before its competitors.

In order to distinguish the degree of novelty of innovation, our dependent variable takes the value equal to 0 when the firm did not introduce innovation; equal to 1 when the firm introduced an innovation to the firm (new-to-the-firm); equal to 2 when the firm introduced an innovation to the industry (new-to-the-industry); and equal to 3 if the firm introduced an innovation to the world (new-to-the-world).

This kind of measure of innovation is a contribution of our paper, since few studies have been used it. In Brazil, the number of firms that introduced innovations to the world is small, only $3.5 \%$ (Table 1 ). On the other hand, there are several firms that have not introduced any innovations in the analysed period (44.8\%), which shows the low level of innovation in the country.

Table 1: Degree of Novelty of the Innovation distribution of firm sample - 2009 to 2011.

\begin{tabular}{lll}
\hline Degree of Novelty & \# of firms & \% offirms \\
\hline Did not innovate & 3218 & 44.8 \\
New-to-the-firm & 2450 & 34.1 \\
New-to-the-industry & 1260 & 17.5 \\
New-to-the-world & 253 & 3.5 \\
\hline & 7181 &
\end{tabular}

One of the main reasons for the weak innovative performance is the weak engagement of firms in technological activities, particularly in Research and Development (R\&D). In contrast to advanced countries, universities, but not the firms, account for most of the R\&D expenditure and employ scientists and engineers (Suzigan et al. 2009). In addition, the competitive conditions in the economy combined by the heterogeneity of Brazilian regions are also factors that affect technological activities. Looking at innovation from the point of view of location, the drives are diverse and can vary widely (Garcia et al. 2015). Due to those reasons, there are several studies that deal to understand how and why different local factors can make firms more prone to innovate.

\subsection{Explanatory Variables}

Our main variable of interest is a binary variable for firms that used public support. We differ two kinds of funding: first, the public support for R\&D, this is, the firm that used public support for R\&D activities (including external acquisition) and second, public support for general activities that involve firms that used public funding for both R\&D 
and non-R\&D (involve the acquisition of goods, services and external knowledge). Both are measured in 2008.

\section{Public support for R\&D and General Activities}

In table 2 and 3 we present the percentage of firms that used public support for R\&D and general activities, respectively, in 2008 by degree of novelty of innovation in 2009$2011^{2}$.

Table 2: Distribution of firm that used public support for R\&D

\begin{tabular}{lllllll}
\hline \multirow{2}{*}{ Degree of Novelty in 2009-2011 } & \multicolumn{6}{l}{ Public Support for R\&D in 2008 } \\
\cline { 2 - 7 } & \multicolumn{2}{c}{ Not Receive } & Receive & Total & \\
\cline { 2 - 7 } & $\#$ & $\%$ & $\#$ & $\%$ & $\#$ & $\%$ \\
\hline Did not innovate & 3164 & 45.9 & 55 & 19.3 & 3218 & 44.8 \\
New-to-the-firm & 2347 & 34.0 & 103 & 36.5 & 2450 & 34.1 \\
New-to-the-industry & 1172 & 17.0 & 88 & 31.1 & 1260 & 17.5 \\
New-to-the-world & 215 & 3.1 & 37 & 13.2 & 253 & 3.5 \\
\hline Total & 6898 & & 283 & & 7181 & \\
\hline
\end{tabular}

Table 2 shows that almost 4\% $(283 / 7,181)$ of firms used public support for R\&D activities in 2008. Evaluating by the degree of novelty of innovation, it is possible to observe that the percentage of firms that introduced some degree of novelty of innovation in 2009-2011 is bigger for firms that used public support for R\&D in 2008 (e.g. new-to-the-world is $3.5 \%$ in total and $13.2 \%$ in firms that got public support). In additional, the percentage of firms that did not innovate is lower for firms that received public support (i.e. $45,9 \%$ firms that did not receive and $19.3 \%$ firms that received). This result can indicate that the public support for $R \& D$ is important to firm's innovation output be of higher novelty.

\begin{tabular}{|c|c|c|c|c|c|c|}
\hline \multirow{3}{*}{ Degree of Novelty in 2009-2011 } & \multicolumn{6}{|c|}{$\begin{array}{l}\text { Public Support for General Activities } \\
(R \& D \text { and non-R\&D) in } 2008\end{array}$} \\
\hline & \multicolumn{2}{|c|}{ Not Receive } & \multicolumn{2}{|c|}{ Receive } & \multicolumn{2}{|c|}{ Total } \\
\hline & \# & $\%$ & \# & $\%$ & \# & $\%$ \\
\hline Did not innovate & 2665 & 46.8 & 553 & 37.4 & 3218 & 44.8 \\
\hline New-to-the-firm & 1831 & 32.1 & 619 & 41.8 & 2450 & 34.1 \\
\hline New-to-the-industry & 1022 & 17.9 & 238 & 16.1 & 1260 & 17.5 \\
\hline New-to-the-world & 182 & 3.2 & 71 & 4.8 & 253 & 3.5 \\
\hline Total & 5700 & & 1481 & & 7181 & \\
\hline
\end{tabular}

Similarly, the exception of the new-to-the-industry, receiving public support for general activities (R\&D and non-R\&D) increase the percentage of firms in higher degree of novelty (e.g. the percentage of new-to-the-world is $3.2 \%$ for firms that did not receive and $4.8 \%$ firms that received, table 3 ).

In addition, comparing the percentages of firms got public support by degree in Tables 2 and 3 , it is possible to observe that the percentage almost doubles in the degree of novelty to the industry $(16,1 \%$ vs $31,1 \%)$ and more than triples to the world $(4,2 \%$ vs $13,2 \%)$. This result ca be indicate that the public support for R\&D have a greater impact

2 This support can be prevenient for FINEP, BNDES, SEBRAE, BB, and other. 
on the generation of innovations of higher degree of novelty than public support for general activities (R\&D and non-R\&D).

\section{Determinants Controls}

In addition to the main variable of interest we consider several key attributes at the firm and region level can be associate with creation and diffusion of knowledge that promote innovation, as scribe below.

Collaboration: a binary variable taking the value 1 when the firm is involved in cooperative arrangements with other organization(s) with a goal to developing innovative activities ${ }^{3}$. Capital Control: for each capital control we used an ordinal variable takes values: 1 - national; 2- foreign and 3- mix. Input Intensity: we measure two forms: R\&D expenditure we measure the share of $R \& D$ expenditure in firm' gross value of industrial production (GVP) and general innovation activity expenditure we utilize share of innovation activity expenditure in firm' gross value of industrial production (GVP). Productivity is measure by natural logarithm the share industrial added value firm' employees. Firm Size is measure by natural logarithm of number of employees. Finally, we added regional variables and sector control that which will not be exposed in this work.

\section{Empirical Results}

\subsection{The association between degrees of novelty and public support}

In order to explore the relation between the degree of novelty of innovation and public support, we apply the generalized form of the ordered probit model. This allows for estimating different coefficients for different categories and it is indicated in cases in which the dependent variable is categorical and the proportional odds assumption is violated. The benefit of generalized ordered probit model (GOPM) over a standard ordered probit model (OPM) is that one can use the information contained in the ordinal dependent variable without the restriction of parallel regressions for the different categories of the dependent variable. The parallel regression assumption, sometimes referred to as the proportional odds assumption, of an ordered probit model is where all the $\beta \mathrm{j}$ 's are restricted to be equal across the different categories of the dependent variable. Relaxing this restriction is warranted due to the fact that the explanatory variables may not affect all groups equally. This effectively causes the generalized ordered probit model to allow for different parameter vectors - one for each move from one category of the dependent variable to the next (Williams 2016).

Each model give us three column of estimates of the binary models, since we have four categories (did no innovate - 0; new-to-the-firm - 1, new-to-the-industry - 2 and new-tothe-world - 3). The first column contrasts firms with no innovation (dependent variable equal 0), with firm's innovative (dependent variable more than 0 ). The second column contrasts firms with dependent variable equal to 0 or 1 (no innovative or new-to-the-

\footnotetext{
3 According to PINTEC (2008) cooperation for innovation means "active participation in joint R\&D projects and other innovation projects with another organization(s) - firm or intitution. This does not necessarily imply that the parties involved derive immediate benefits. The simple hiring of services of another organization, without their collaboration" (Publication PINTEC 2008 p.153)
} 
firm), with firms having dependent variable equal to 2 or 3 (new-to-the industry or world). The last column contrasts firms with dependent variable less than 3 , with firms that have a dependent variable equal to 3, i.e. firms that exhibit the highest degree of novelty of innovation (new-to-the-world). Tables 4 and 5 present the results of the econometric analysis to public support for R\&D and for general activities, respectively.

Table 4: GOPM estimating relationship between public support for R\&D and degree of novelty

\begin{tabular}{|c|c|c|c|}
\hline Variable & $\begin{array}{l}\text { Firms with no } \\
\text { innovation contrasted } \\
\text { with more innovative } \\
\text { firms }\end{array}$ & $\begin{array}{l}\text { Firms with no or "new } \\
\text { to the firm "innovation } \\
\text { compared to firms with } \\
\text { more radical innovation }\end{array}$ & $\begin{array}{l}\text { Firms with no or less radical } \\
\text { innovation compared to firms } \\
\text { with "new to the world } \\
\text { "innovation }\end{array}$ \\
\hline \multirow{2}{*}{ Public Support for R\&D } & $0.490 * * *$ & $0.495 * * *$ & $0.434 * * *$ \\
\hline & $(0.178)$ & $(0.129)$ & $(0.158)$ \\
\hline \multirow{2}{*}{$R \& D$ expenditure } & $1.627^{*}$ & 0.387 & $1.400 * *$ \\
\hline & $(0.850)$ & $(0.348)$ & $(0.546)$ \\
\hline \multirow{2}{*}{ Size } & $0.142 * * *$ & $0.163 * * *$ & $0.192 * * *$ \\
\hline & $(0.0303)$ & $(0.0288)$ & $(0.0306)$ \\
\hline \multirow{2}{*}{ Productivity } & $0.197 * * *$ & $0.198 * * *$ & $0.119 * * *$ \\
\hline & $(0.0520)$ & $(0.0438)$ & $(0.0456)$ \\
\hline \multirow{2}{*}{ Cooperation } & $0.168 *$ & $0.194 * *$ & 0.146 \\
\hline & $(0.0972)$ & $(0.0872)$ & $(0.0923)$ \\
\hline \multirow{2}{*}{ National vs Foreign } & 0.0534 & $0.350 * * *$ & $0.266 * * *$ \\
\hline & $(0.110)$ & $(0.0998)$ & $(0.100)$ \\
\hline \multirow{2}{*}{ National vs Mix } & -0.326 & -0.145 & -0.114 \\
\hline & $(0.205)$ & $(0.164)$ & $(0.240)$ \\
\hline \multirow{2}{*}{ Constant } & $-2.194 * * *$ & $-4.829 * * *$ & $-6.462 * * *$ \\
\hline & $(0.837)$ & $(1.099)$ & $(0.852)$ \\
\hline \multirow[t]{9}{*}{$\begin{array}{l}\text { Setorial an } \\
\text { Controls }\end{array}$} & Yes & Yes & Yes \\
\hline & r2_p: 0.0867 & & \\
\hline & 11: -4281 & & \\
\hline & 11_0: -4687 & & \\
\hline & p: 0 & & \\
\hline & chi2: 2152 & & \\
\hline & df_m: 57 & & \\
\hline & rank: 60 & & \\
\hline & ic: 9 & & \\
\hline Number of obs. & $4,077 * \mathrm{pw}=7181$ & & \\
\hline
\end{tabular}

Our results indicate that public financing for R\&D is associated degree of novelty of the innovation (table 4). The coefficients are positive and significant in three column of support public for R\&D variable, suggesting that there is significant difference in terms degree of novelty of innovation between firms that got public support R\&D and firms that do not obtain. This is, means that firms that used public support for R\&D are more likely to launch innovation(s) of higher degree compared to firms not obtain. Specifically, effect on each degree of novelty is similar (variable did not violates the proportional odds assumption), and we can interpreted like, firm`s that received public support for $\mathrm{R} \& \mathrm{D}$ are more likely to engage in radical innovation activities than firms did not received. If other independent variables in the model are held constant, firms that used public support for R\&D increase by 0.434 the chance to introduce more radical innovation than firms do not receive. 
Table 5: GOPM estimating relationship between public support for general activities (R\&D an non-R\&D) and degree of Novelty of Innovation

\begin{tabular}{|c|c|c|c|}
\hline Variable & $\begin{array}{l}\text { Firms with no } \\
\text { innovation } \\
\text { contrasted with more } \\
\text { innovative firms }\end{array}$ & $\begin{array}{l}\text { Firms with no or "new to } \\
\text { the firm "innovation } \\
\text { compared to firms with } \\
\text { more radical innovation }\end{array}$ & $\begin{array}{l}\text { Firms with no or less radical } \\
\text { innovation compared to firms } \\
\text { with "new to the world } \\
\text { "innovation }\end{array}$ \\
\hline \multirow{2}{*}{$\begin{array}{l}\text { Public Support for } \\
\text { General Activities }\end{array}$} & $0.239 * *$ & 0.0583 & $0.206^{* *}$ \\
\hline & $(0.0982)$ & $(0.0879)$ & $(0.0988)$ \\
\hline \multirow{2}{*}{$\begin{array}{l}\text { General } \\
\text { expenditure }\end{array}$} & $0.540 * * *$ & $0.531 * * *$ & 0.328 \\
\hline & $(0.188)$ & $(0.192)$ & $(0.328)$ \\
\hline \multirow{2}{*}{ Size } & $0.143 * * *$ & $0.172 * * *$ & $0.181 * * *$ \\
\hline & $(0.0296)$ & $(0.0284)$ & $(0.0322)$ \\
\hline \multirow{2}{*}{ Productivity } & $0.218 * * *$ & $0.222 * * *$ & $0.129 * * *$ \\
\hline & $(0.0511)$ & $(0.0430)$ & $(0.0483)$ \\
\hline \multirow{2}{*}{ Cooperation } & $0.163 *$ & $0.214 * *$ & $0.196 * *$ \\
\hline & $(0.0946)$ & $(0.0862)$ & $(0.0942)$ \\
\hline \multirow{2}{*}{ National vs Foreign } & 0.0728 & $0.338 * * *$ & $0.288 * * *$ \\
\hline & $(0.111)$ & $(0.101)$ & $(0.102)$ \\
\hline \multirow{2}{*}{ National vs Mix } & -0.281 & -0.136 & -0.0627 \\
\hline & $(0.199)$ & $(0.161)$ & $(0.239)$ \\
\hline \multirow{2}{*}{ Constant } & $-2.309 * * *$ & $-4.926 * * *$ & $-6.476 * * *$ \\
\hline & $(0.819)$ & $(1.075)$ & $(0.820)$ \\
\hline \multirow[t]{9}{*}{$\begin{array}{l}\text { Sectorial and } \\
\text { Regional Controls }\end{array}$} & Yes & Yes & Yes \\
\hline & r2_p: 0.0881 & & \\
\hline & 11: -4275 & & \\
\hline & 11_0: -4687 & & \\
\hline & p: 0 & & \\
\hline & chi2: 2339 & & \\
\hline & df_m: 57 & & \\
\hline & rank: 60 & & \\
\hline & ic: 8 & & \\
\hline Number of obs. & $4,077 * \mathrm{pw}=7,181$ & & \\
\hline
\end{tabular}

Regarding the public support for general activities (R\&D and non-R\&D), the coefficients are positive and significant in the first and third columns (table 5). This result indicate that there is a difference between firms supported for general innovation activities and non-supported firms in the proportion who innovate versus those who do not (first column) and who radically innovate (third column).

In addition, the significant coefficients of public financing for general activities indicate that firms that used public support for general activity are more likely to generate radically innovation than firms that did not use. In additional, the coefficient not significant in the second column suggesting that there is no significant difference between firms that used public support for general activity and firms did not use in the proportion in the proportion who don't innovate or innovate at the firm level and those who innovate at the industry or the world level (i.e. radically innovate). Therefore, the result illustrate that the public support for general activities variable violates the proportional odds assumption, indicating that the effect of public support for general activity is asymmetrical between the different degrees of novelty of innovation. 
The results of the controls variables are in line with expectations (tables 4 and 5). Firms with more innovation expenditure or productive or large firms appear to be more prone to higher degree of innovation. Regarding cooperation variable, the coefficients are significant in almost all the estimates of the two models, suggesting that firms that cooperation with other agents tend to present higher-level innovations when compared to non-cooperating firms. In adition, firms with foreign capital tend to generate innovations of a higher degree of novelty than firms with national capital.

Comparing the coefficients values of the public support for R\&D and general activities (R\&D and non-R\&D), table 4 and 5, the results obtained show higher values for public support for R\&D (0.49 vs 0.24$)$. This result can suggest the chances that firms launch radical innovations are higher for firms that receive public support for R\&D than for general activities. Agreeing with prior literature (Freeman and Soete 2008), this finding clearly demonstrates that although degree of novelty of the innovation is associated with public support, high risk activities such as radical innovation envolve more funding related to $R \& D$ than general activities.

\subsection{The marginal effects of variables on degree of novelty of innovation}

After verifying the relationship between public support for R\&D and general activities and degree of novelty of innovation, we calculate the marginal effects within each degree of novelty for two models (tables 6 and 7). The generalized ordered probit model does not treat the threshold values as constants but makes them dependent on regressors. This implies the relative marginal probability effects are not constant and that the marginal probability effects can change their sign more than once as one moves from the smallest to the largest outcome. Thus, it allows for more flexibility in the estimation of the marginal probability effects than the simple ordered probit model.

Table 6: Marginal effects based on generalized ordered probit model (GOP). Degree of Novelty of Innovation

\begin{tabular}{|c|c|c|c|c|}
\hline Variable & $\begin{array}{l}\text { Did not } \\
\text { innovate }\end{array}$ & $\begin{array}{l}\text { New-to- } \\
\text { the-firm }\end{array}$ & $\begin{array}{l}\text { New-to-the- } \\
\text { industry }\end{array}$ & $\begin{array}{l}\text { New-to-the- } \\
\text { world }\end{array}$ \\
\hline Public Support for R\&D & $\begin{array}{l}-0.193 * * * \\
(0.070)\end{array}$ & $\begin{array}{l}0.064 \\
(0.060)\end{array}$ & $\begin{array}{l}0.112 * * * \\
(0.032)\end{array}$ & $\begin{array}{l}0.017 * * * \\
(0.006)\end{array}$ \\
\hline$R \& D$ expenditure & $\begin{array}{l}-0.642 * \\
(0.336)\end{array}$ & $\begin{array}{l}0.541 \\
(0.331)\end{array}$ & $\begin{array}{l}0.047 \\
(0.080)\end{array}$ & $\begin{array}{l}0.055 * * \\
(0.022)\end{array}$ \\
\hline Size & $\begin{array}{l}-0.056^{* * *} \\
(0.012)\end{array}$ & $\begin{array}{l}0.013 \\
(0.011)\end{array}$ & $\begin{array}{l}0.035^{* * * *} \\
(0.006)\end{array}$ & $\begin{array}{l}0.008^{* * * *} \\
(0.001)\end{array}$ \\
\hline Productivity & $\begin{array}{l}-0.078 * * * \\
(0.021)\end{array}$ & $\begin{array}{l}0.026 \\
(0.017)\end{array}$ & $\begin{array}{l}0.047 * * * \\
(0.011)\end{array}$ & $\begin{array}{l}0.005^{* * * *} \\
(0.002)\end{array}$ \\
\hline Cooperation & $\begin{array}{l}-0.066^{*} \\
(0.038)\end{array}$ & $\begin{array}{l}0.012 \\
(0.032)\end{array}$ & $\begin{array}{l}0.045 * * \\
(0.021)\end{array}$ & $\begin{array}{l}0.006 \\
(0.004)\end{array}$ \\
\hline National vs Foreign & $\begin{array}{l}-0.021 \\
(0.044)\end{array}$ & $\begin{array}{l}-0.071 * * \\
(0.032)\end{array}$ & $\begin{array}{l}0.081 * * * \\
(0.025)\end{array}$ & $\begin{array}{l}0.010 * * \\
(0.004)\end{array}$ \\
\hline National vs Mix & $\begin{array}{l}0.128 \\
(0.081)\end{array}$ & $\begin{array}{l}-0.091 \\
(0.056)\end{array}$ & $\begin{array}{l}-0.034 \\
(0.039)\end{array}$ & $\begin{array}{l}-0.005 \\
(0.009)\end{array}$ \\
\hline $\begin{array}{l}\text { Setorial and Regional } \\
\text { Controls }\end{array}$ & Yes & Yes & Yes & Yes \\
\hline Number of obs. & \multicolumn{4}{|c|}{$4,077 * \mathrm{pw}=7,181$} \\
\hline
\end{tabular}

The results show that firms that used public support for R\&D decrease the probability of don't innovate by $19.3 \%$ percentage points. In addition, the probability of innovate to 
the industry and world raises about 11.2 and 1.7 percentage points, respectively, for firms that used public support for R\&D. There is no effect on new-to-the firm. This result suggests that higher risk financial resources such as $R \& D$ are associated with radical rather than incremental innovations (table 6).

Regarding firms that used public support for general activities (table 7), the probability of don't innovate is reduced by 9.5 percentage points. Moreover, the results show that firms that used public support for R\&D raises the probability of innovate at the firm by 7,9 percentage points. This result reveals that the combination of public support for $R \& D$ and non-R\&D are especially relevant to promote incremental innovation, as newto-the-firm. There is no effect on degree of new-to-the-industry, but and there is effect on new-to-the-world.

If we compare the effects of public support for $R \& D$ and for general activities (table 6 vs 7), the results show that the effect on degrees of novelty is biggest for firms that used public support for R\&D than general activities. For example, don't innovate is reduced by 19.3 percentage points percentage points for firms that got public support for R\&D and by 9.5 percentage points for firms received public support for general activities. These results indicate the importance of targeting public funding for R\&D.

Table 7: Marginal effects based on generalized ordered probit model (GOP). Degree of Novelty of

\begin{tabular}{lllll}
\hline \multicolumn{5}{c}{ Innovation } \\
Variable & $\begin{array}{l}\text { Did not } \\
\text { innovate }\end{array}$ & $\begin{array}{l}\text { New-to- } \\
\text { the-firm }\end{array}$ & $\begin{array}{l}\text { New-to-the- } \\
\text { industry }\end{array}$ & $\begin{array}{l}\text { New-to- } \\
\text { the-world }\end{array}$ \\
\hline Public Support for General Activities & $-0.095^{* *}$ & $0.079^{* *}$ & 0.007 & $0.008^{* *}$ \\
& $(0.039)$ & $(0.038)$ & $(0.021)$ & $(0.004)$ \\
General activities expenditure & $-0.213^{* * *}$ & 0.074 & $0.125^{* *}$ & 0.013 \\
Size & $(0.074)$ & $(0.056)$ & $(0.051)$ & $(0.014)$ \\
& $-0.057^{* * *}$ & 0.012 & $0.038^{* * *}$ & $0.007^{* * *}$ \\
Productivity & $(0.012)$ & $(0.010)$ & $(0.006)$ & $(0.001)$ \\
& $-0.086^{* * *}$ & 0.028 & $0.053^{* * *}$ & $0.005^{* * *}$ \\
Cooperation & $(0.020)$ & $(0.017)$ & $(0.010)$ & $(0.002)$ \\
& $-0.064^{*}$ & 0.008 & $0.048^{* *}$ & $0.008^{* *}$ \\
National vs Foreign & $(0.037)$ & $(0.031)$ & $(0.021)$ & $(0.004)$ \\
& -0.029 & $-0.060^{*}$ & $0.077^{* * *}$ & $0.012^{* * *}$ \\
National vs Mix & $(0.044)$ & $(0.032)$ & $(0.026)$ & $(0.004)$ \\
Sectorial and Regional Controls & 0.111 & -0.075 & -0.033 & -0.003 \\
Number of obs. & $(0.079)$ & $(0.055)$ & $(0.039)$ & $(0.010)$ \\
\end{tabular}
Note $* * * p<0.01, * * p<0.05, * p<0.1$

\section{Conclusion}

Over time studies have sought to understand the determinants and their effect on innovative activity. However, much less attention has been given to the quality of innovation, part of this due to the difficulty of finding data at the firm level and measures of the quality of innovation. In this context, this study seeks to explore the determinants of the degree of novelty of the innovations in Brazil, and in particular to evaluate the relationship between two kinds of public support, R\&D and general, and innovation performance. 
We used a generalized ordered probit model to estimate coefficients for different the degrees of novelty of the innovation. Our results show that public support plays an important role in shaping Brazilian firms innovative performance in terms of market. Firms that got public support are more likely to launch innovation compared firms that did not get. In addition, our results indicate that distinct public support has a different impact in the degree of novelty of innovation. Public support for R\&D are associated radically innovations (new-to-the-industry and new-to-the-world), while public support for general activities tend to increase just the incremental innovation (new-to-the-firm). 


\section{References}

Amara, Nabil, Réjean Landry, Nizar Becheikh, and Mathieu Ouimet. 2008. "Learning and Novelty of Innovation in Established Manufacturing SMEs." Technovation 28 (7): 450-63. https://doi.org/10.1016/j.technovation.2008.02.001.

Arbix, Glauco, and Flávia Consoni. 2011. "Inovar Para Transformar a Universidade Brasileira." Revista Brasileira de Ciências Sociais 26 (77): 205-24.

Brasil. 2004. "Law 10,973." 2004. http://www.planalto.gov.br/ccivil_03/_ato20042006/2004/lei/110.973.htm.

. 2005. "Law 11,196." 2005. http://www.planalto.gov.br/ccivil_03/_Ato20042006/2005/Lei/L11196.htm.

Cin, Beom Cheol, Young Jun Kim, and Nicholas S. Vonortas. 2017. "The Impact of Public R\&D Subsidy on Small Firm Productivity: Evidence from Korean SMEs." Small Business Economics 48 (2): 345-60. https://doi.org/10.1007/s11187-0169786-x.

Cohen, Wesley M, and Daniel a Levinthal. 1990. "Absorptive Capacity: A New Perspective on Learning and Innovation Wesley M . Cohen; Daniel A . Levinthal Absorptive Capacity: A New Perspective on Learning and Innovation." Administrative Science Quarterly 35 (1): 128-52. https://doi.org/10.2307/2393553.

Colombo, Daniel Gama e, and Helio Nogueira da Cruz. 2018. Impacts of the Brazilian Innovation Tax Policy on the Composition of Private Investments and on the Type of Innovation. Revista Brasileira de Inovação. Vol. 17. https://doi.org/10.20396/rbi.v17i2.8651500.

Feldman, Maryann P., and Maryellen R. Kelley. 2003. "Leveraging Research and Development: Assessing the Impact of the U.S. Advanced Technology Program." Small Business Economics 20 (2): https://doi.org/10.1023/A:1022264031993.

"FINEP." n.d. Accessed May 18, 2019. http://www.finep.gov.br/afinep/65-fontes-derecurso/fundos-setoriais.

Freeman, C, and L Soete. 2008. A Economia Da Inovação Industrial. Campinas: Editora Da Unicamp.

Garcia, Renato, Veneziano Araujo, Suelene Mascarini, Emerson Gomes Santos, and Ariana Costa. 2015. "Looking at Both Sides: How Specific Characteristics of Academic Research Groups and Firms Affect the Geographical Distance of University--Industry Linkages." Regional Studies, Regional Science 2 (1): 518-34.

Georghiou, L. 1994. "Impact of the Framework Programme on European Industry. EUR 15907 EN." Luxembourg: Office for Official Publications of the EC.

Georghiou, Luke. 2002. "Impact and Additionality of Innovation Policy." IWT Studies 40: 57-64.

Jr, Kannebley, Sergio, and Geciane Porto. 2012. "Incentivos Fiscais à Desenvolvimento e Inovação No Brasil : Uma Avaliação Das Políticas Incentivos Fiscais à Pesquisa, Desenvolvimento e Inovação No Brasil : Uma Avaliação Das Políticas." Banco Interamericano de Desenvolvimento - DOCUMENTO PARA DISCUSSÃO, 1-57.

Júnior, Sérgio Kannebley, and Diogo de Prince. 2015. "Restrição Financeira e 
Financiamento Público à Inovação No Brasil: Uma Análise Com Base Em Microdados Da PINTEC." Nova Economia 25 (3): 553-74. https://doi.org/10.1590/0103-6351/2078.

Manual, Oslo. 2005. "The Measurement of Scientific and Technological Activities." Proposed Guidelines for Collecting an Interpreting Technological Innovation Data.

McDermott, Christopher M, and Gina Colarelli O'Connor. 2002. "Managing Radical Innovation: An Overview of Emergent Strategy Issues." Journal of Product Innovation Management 19 (6): 424-38.

Neicu, Daniel, Peter Teirlinck, and Stijn Kelchtermans. 2016. "Dipping in the Policy Mix: Do R\&D Subsidies Foster Behavioral Additionality Effects of R\&D Tax Credits?" Economics of Innovation and New Technology 25 (3): 218-39. https://doi.org/10.1080/10438599.2015.1076192.

Rapini, Márcia Siqueira. 2013. "Padrão De Financiamento Aos Investimentos Em Inovação No Brasil." TEXTO PARA DISCUSSÃO TEXTO PARA. http://www.cedeplar.ufmg.br/pesquisas/td/TD 497.pdf.

Suzigan, Wilson, Eduardo Albuquerque, Renato Garcia, and Marcia Rapini. 2009. "University and Industry Linkages in Brazil: Some Preliminary and Descriptive Results." Seoul Journal of Economics 22 (4): 591-611. https://doi.org/http://www.sje.ac.kr.

Williams, Richard. 2016. "Understanding and Interpreting Generalized Ordered Logit Models." Journal of Mathematical Sociology $40 \quad$ (1): 7-20. https://doi.org/10.1080/0022250X.2015.1112384. 